\title{
Trend Analyses of Parameters of Equations for Minimum CBR Distance Achievable in Ubicomp MANETs Using Location-Aware Transmission.
}

\author{
M. Kaleem GALAMALI, Assoc. Prof Nawaz MOHAMUDALLY
}

\begin{abstract}
Use of MANET transmission approaches symbolise a key towards solving the problem of sparsely available network and routing equipment in ubicomp environments, which is expected to be the case for many future environments specially outdoor ones. Good performance of MANET directly depends on correctly designed protocols and research is well on the way in this direction [79]. The adaptation of location-aware transmission strategies is prone to augment energy management standards and justifies all the effort put in by researchers. Among the technological enrichments looked forward in the future, the application of landbased GPS systems, improved location refresh rates and accuracy, development of fine-tuned transmission protocols and cheaper sophisticated hardware, are most awaited. Available scientific knowledge of trends of distance coverages by transmitted packets in a ubicomp over varying node densities, is undeniably favourable for refining transmission protocols in MANETs. Correspondingly, one such empirical study was carried out in a previous paper [28], whereby metric Min_CBR_Dist was explained.
\end{abstract}

In this paper, the next piece of investigation required for metric Min_CBR_Dist is put forward as: "What are the trends of variation observable within each parameter of the equation of curves obtained for metric Min_CBR_Dist [28] over varying node densities?". The results presented here remain utilisable by designers for better developing ubicomp transmission protocols. This piece of research remains a follow-up of previous work [1-43].

Key terms: Ubicomp- Ubiquitous Computing, MAUCMobile and Ubiquitous Computing, MANET- Mobile Adhoc Network, CBR- Constant Bit Rate, Min_CBR_Dist - Minimum CBR Distance.

M. Kaleem GALAMALI,

University of Technology Mauritius (student) Mauritius

Assoc. Prof Nawaz Mohamudally

University of Technology Mauritius, Mauritius

\section{Introduction}

Ubicomp topographies may not all be sophisticatedly equipped with networking and routing devices. Many such topographies, specially outdoor ones and those in lesser developed regions, may be poorly equipped. It is also expected that, since ubicomp inherits from distributed systems, it will still be subject to lots of inherent heterogeneities [1]. MANET transmission may also be having such heterogeneities in their operating protocols. Nevertheless, MANET transmission remain a favourable choice for poor topographies. It remains possible to enhance MANET transmission with incorporation of location-aware transmission features. Methods of studying distance related characteristics experienced by CBRs in ubicomp may also be built from metrics. One such metric, Min_CBR_Dist was studied previously [28], whereby pattern followed was expressed as exponential model of form:

$F(x)=a * \exp (b *(x-c))+d$

Here, the moderately complex equation of the model has involved 4 parameters: $\mathrm{a}, \mathrm{b}, \mathrm{c}$ and $\mathrm{d}$. the next empirical formulation required for metric Min_CBR_Dist is the model equations for parameters of equation specified above.

The key contributions of this paper is the development of equations involved for the model for metric Min_CBR_Dist presented previously [28], from which table 1 is re-used here. The empirical methods provided here remain usable by designers and programmers, to be implemented into software simulators so that these can be further empowered for advanced investigations of the evolution and predictability of distance features in future ubicomp. The rest of this paper is organised as follows: section 2- Parameter Trend Analysis- Metric Min_CBR_Dist, section 3-Conclusion and References.

\section{Parameter Trend Analysis - Metric Min_CBR_Dist.}

\subsection{General Procedure Adopted.}

The procedure adopted consist of 4 steps:

i. The tabulated data for each parameter of the equation for the model for Min_CBR_Dist is plotted onto gnuplot.

ii. Graphical analyses are performed and general observations are noted. 
Proc. of the Seventh International Conference On Advances in Computing, Electronics and Electrical Technology - CEET 2017. Copyright (C) Institute of Research Engineers and Doctors. All rights reserved.

ISBN: 978-1-63248-126-9 doi: 10.15224/ 978-1-63248-126-9-17

iii. Different equations of fit are tried. Criteria of value of least reduced chi-square and most appreciable extendability at node numbers 80, 100 and 120 .

iv. The parameter values for each Min_CBR_Dist parameter of equation is noted.

\subsection{Trend Analysis - Min_CBR_Dist parameter " $a$ ”.}

Generally the tendency observed is a decreasing trend at a decreasing rate. A small oscillation along this trend is also depicted. However, the oscillation is of negligible amplitude. The plot at node number 7 appears as an outlier and different results may be obtained for trend, if reworked with different starting values of parameters.

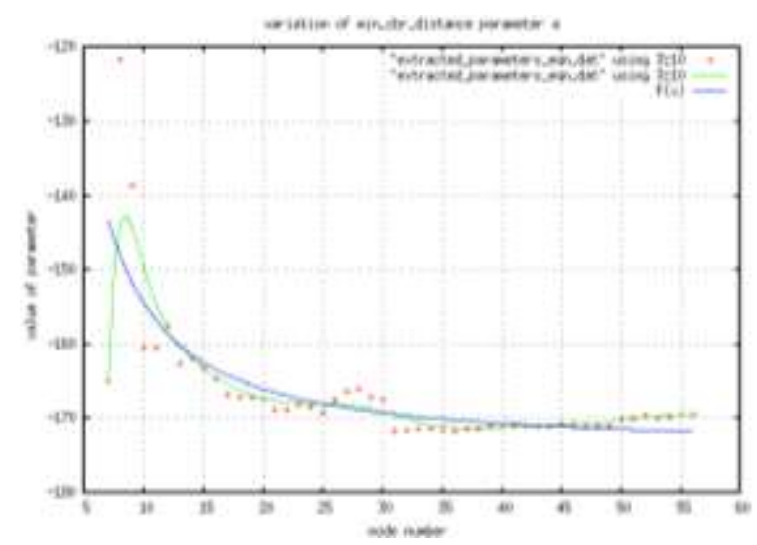

Figure 1: Min_CBR_Dist parameter a

The potentially applicable equations of trend are :

$$
\begin{array}{rl}
\text { 1. } F(x)=(a / x) \star \log & (b \star x)+c \\
C h \_s q=32.7487 & F(80)=-173.898 \\
F(100)=-174.534559 & F(120)=-174.966459 \\
\text { 2. } F(x)=\left(a * x^{-1.5}\right) & \star \log (b * x)+c \\
\text { Ch_sq }=31.7469 & F(80)=-172.484578 \\
F(100)=-172.792915 & F(120)=-172.984049 \\
\text { 3. } F(x)=\left(a * x^{d}\right) \star \log (b \star x)+c \\
\text { Ch_sq }=32.4351 \quad F(80)=-172.335116 \\
F(100)=-172.618633 & F(120)=-172.792926
\end{array}
$$

\section{Choice of best fit for Min_CBR_Dist Parameter a}

The equation in part 2 above has been selected because of smallest ch_sq and good extendability over larger node numbers. The parameters obtained for best fit are:

$a=113.292, b=20.602, c=-173.657$

\subsection{Trend Analysis - Min CBR_Dist parameter "b".}

Generally, the plots depict a decreasing tendency. A slight non-uniform oscillation is also depicted and a few plots appear as outliers.

The equation of best fit is:

$$
\begin{gathered}
F(x)=a \star x+b \\
\text { Ch_sq }=0.000465458 \quad F(80)=-0.207555245
\end{gathered}
$$

$$
\mathrm{F}(100)=-0.260474
$$$$
F(120)=-0.313392767
$$

The parameters of fit are :

$$
a=-0.00264594, b=0.0041198
$$

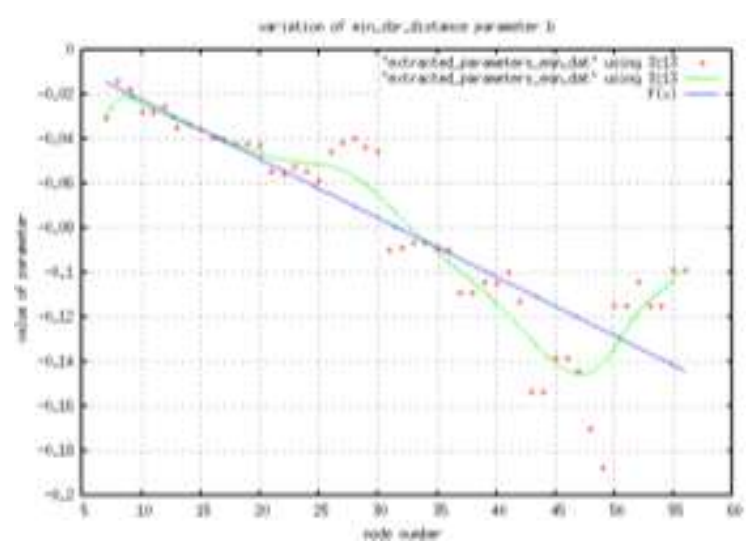

Figure 2: Min _CBR_Dist parameter b

\subsection{Trend Analysis - Min CBR Dist parameter "c".}

Generally the plot depicts an increasing tendency at a decreasing rate. The plot for node number 7 appears as an outlier.

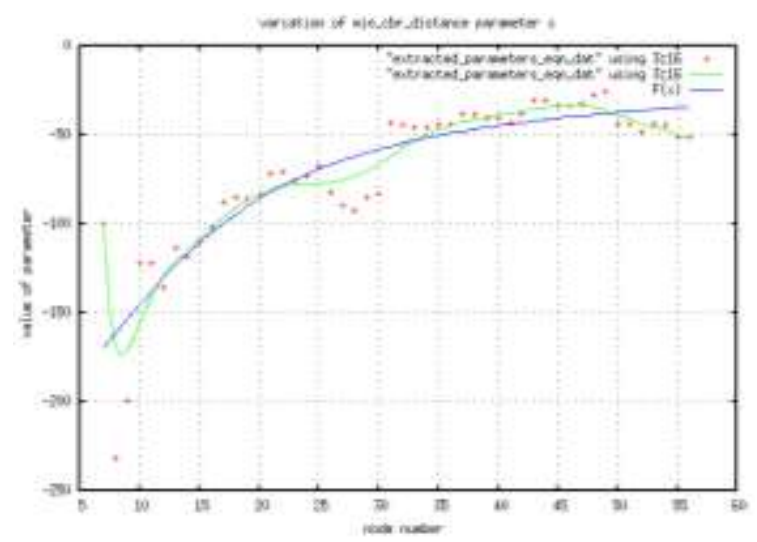

Figure 3: Min _CBR_Dist parameter c

The potentially applicable equations of trend are:

$$
\begin{aligned}
& \text { 1. } F(x)=\left(\left(a * x^{2}\right) /\left(\operatorname { e x p } \left(\left(b \star x^{h}\right)\right.\right.\right. \\
& +C)))+f \star x^{-1} \star \log (x) \\
& \text { Ch_sq }=415.844 \quad F(80)=-25.836324 \\
& F(100)=-21.717133 \quad F(120)=-18.813776037 \\
& \text { 2. } F(x)=\left(\left(a \star x^{3}\right) /\left(\operatorname { e x p } \left(\left(b \star x^{h}\right)\right.\right.\right. \\
& +C)))+f \star x^{-1} \star \log (x) \\
& \text { Ch_sq }=429.191 \quad F(80)=-18.484 \\
& F(100)=-13.112886 \quad F(120)=-9.712348 \\
& \text { 3. } F(x)=\left(\left(a * x^{4}\right) /\left(\operatorname { e x p } \left(\left(b * x^{h}\right)\right.\right.\right. \\
& +C)))+f \star x^{-1} \star \log (x) \\
& \text { Ch_sq }=426.716
\end{aligned}
$$

\section{Choice of best fit for Min_CBR_Dist parameter c}

The equation in part 1 above has been selected because of both smallest reduced chi-square value obtained and good extendability. The parameters for best fit are: 
$\mathrm{a}=-1.92719, \mathrm{~b}=0.515555, \mathrm{c}=-1.48059, \mathrm{f}=-$ $471.572, \mathrm{~h}=0.784663$.

\subsection{Trend Analysis - Min_CBR_Dist parameter " $d$ ”.}

The plot depicts an early rapidly increasing tendency reaching a maximum point after which the curve depicts a smoothly decreasing tendency.

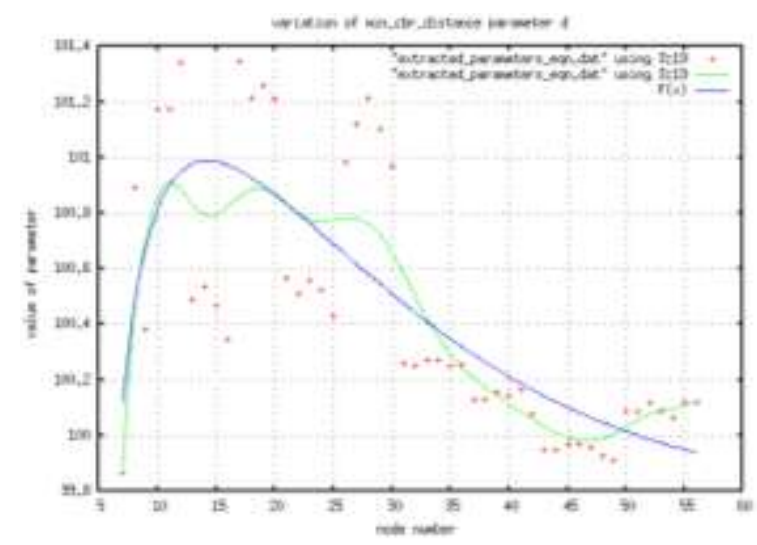

Figure 4: Min_CBR_Dist parameter d

The potentially applicable equations are:

$$
\begin{aligned}
& \text { 1. } F(x)=((a * x+f) /(\exp ((b * x)+c)))+d \\
& \text { Ch_sq }=0.0976895 \quad \mathrm{~F}(80)=99.848642 \\
& \mathrm{~F}(100)=99.835076 \quad \mathrm{~F}(120)=99.832552 \\
& \text { 2. } F(x)=\left(\left(a * x^{-2}+f\right) /(\exp ((b * x)+c))\right)+d \\
& \text { Ch_sq }=0.0971601 \quad \mathrm{~F}(80)=99.687830 \\
& \mathrm{~F}(100)=99.598580 \quad \mathrm{~F}(120)=99.554372 \\
& \text { 3. } F(x)=\left(\left(a * x^{-3}+f\right) /(\exp ((b * x)+c))\right)+d \\
& \text { Ch_sq }=0.0999635 \quad \mathrm{~F}(80)=99.234648 \\
& \mathrm{~F}(100)=98.807891 \quad \mathrm{~F}(120)=98.428515 \\
& \text { 4. } F(x)=\left(\left(a * x^{-2}+f\right) /\left(\exp \left(\left(b * x^{1.5}\right)+c\right)\right)\right)+d \\
& \text { Ch_sq }=0.0961395 \quad \mathrm{~F}(80)=99.804774 \\
& \mathrm{~F}(100)=99.783585 \quad \mathrm{~F}(120)=99.779752
\end{aligned}
$$

\section{Choice of best fit for Min_CBR_Dist parameter d}

The equation in part 4 above has been selected because of both smallest reduced chi-square value obtained and good extendability. The parameters for best fit are:

$\mathrm{a}=-2.73257, \mathrm{~b}=0.00614303, \mathrm{c}=-3.4236, \mathrm{~d}=$ $99.7791, \mathrm{f}=0.0682832$

\section{Conclusion.}

This work of further empirical analysis was designed to and has supplied applicable models of trends of the parameters of equations for the metric Min_CBR_Dist in a MANET topography of $300 \times 300 \mathrm{~m}^{2}$. The models detailed here, encompass mathematical equations of varying complexity. Such theoretical information may impel refined development of processing algorithms for simulator packages for the purpose of advanced studies of MANETs. This empirical research was conducted in gnuplot. Values of least reduced chi-square and best extendability produced at higher node numbers have been used as criteria for selecting best fit.

The sound assumptions made in previous paper [28] are applied here also. The capability and accuracy level of gnuplot is deemed as adequate for the purpose of this investigation.

Additional work identified here remain: formulating a suitable method of predictability for metric Min_CBR_Dist and its trend and reporting specific observations of pertinent critical values highlighted.

\section{References}

[1] M. Kaleem GALAMALI, Assoc. Prof Nawaz MOHAMUDALLY, Towards Dependable Pervasive Systems-A Position and Vision Paper, CEET 2014

[2] M. Kaleem GALAMALI, Assoc. Prof Nawaz MOHAMUDALLY, Model of Energy Savings achievable with Location-aware Node-to-Node Transmission in UbiComp , CEET 2014

[3] M. Kaleem GALAMALI, Assoc. Prof Nawaz MOHAMUDALLY, Model of Energy Savings achievable with Location-aware Node-to-Node Transmission in UbiComp Using Location Refresh Intervals, CEET 2014

[4] M. Kaleem GALAMALI, Assoc. Prof Nawaz MOHAMUDALLY, Model of Energy Savings achievable with Location-aware Transmission in UbiComp Using Relays, CEET 2014

[5] M. Kaleem GALAMALI, Assoc. Prof Nawaz MOHAMUDALLY, Mathematical modeling of need of exact number of relays to ensure seamless mobility in mobile computing, CEET 2014

[6] M. Kaleem GALAMALI, Assoc. Prof Nawaz MOHAMUDALLY, Modelling of need for multiple relays for ensuring seamless mobility, CEET 2014

[7] M. Kaleem GALAMALI, Assoc. Prof Nawaz MOHAMUDALLY, Investigation of prominence of placements of relays in a ubicomp topography,

[8] M. Kaleem GALAMALI, Assoc. Prof Nawaz MOHAMUDALLY, Model of energy savings achievable with location-aware transmission in ubicomp using optimised number of relays.

[9] M. Kaleem GALAMALI, Assoc. Prof Nawaz MOHAMUDALLY, Investigation of Prominence of Placements of Optimised Number of Relays in a Ubicomp Topography using Location-Aware Transmission, CEET 2015.

[10] M. Kaleem GALAMALI, Assoc. Prof Nawaz MOHAMUDALLY, Extending Node Battery Availability in Ubicomp with Location-Aware Transmission, CEET 2015.

[11] M. Kaleem GALAMALI, Assoc. Prof Nawaz MOHAMUDALLY, Extending Node Battery Availability in Ubicomp with Location-Aware Transmission using Location Refresh Intervals, CEET 2015.

[12] M. Kaleem GALAMALI, Assoc. Prof Nawaz MOHAMUDALLY, Extending Node Battery Availability in Ubicomp with Location-Aware Transmission using Uniformly Placed Relays, CEET 2015.

[13] M. Kaleem GALAMALI, Assoc. Prof Nawaz MOHAMUDALLY, Extending Node Battery Availability in Ubicomp with Location-Aware Transmission Using Optimally Placed Relays, CEET 2015.

[14] M. Kaleem GALAMALI, Assoc. Prof Nawaz 
MOHAMUDALLY, Model of Sender Node Energy Savings Achievable with Location-Aware MANET Transmission in Ubicomp. ACCN 2016

[15] M. Kaleem GALAMALI, Assoc. Prof Nawaz MOHAMUDALLY, Model of Overall Node Energy Savings Achievable with Location-Aware MANET Transmission in Ubicomp. ACCN 2016

[16] M. Kaleem GALAMALI, Assoc. Prof Nawaz MOHAMUDALLY, Model of Sender Node Extra Energy Savings Achievable in MANET Against Direct Node-toNode Transmission Using Location-Aware Transmission in Ubicomp. ACCN 2016

[17] M. Kaleem GALAMALI, Assoc. Prof Nawaz MOHAMUDALLY, Model of Overall Node Extra Energy Savings Achievable in MANET against Direct Node-toNode Transmission Using Location-Aware Transmission in Ubicomp. ACCN 2016

[18] M. Kaleem GALAMALI, Assoc. Prof Nawaz MOHAMUDALLY, Model of Energy Consumption Ratio Achievable in MANET Using Location-Aware Transmission in Ubicomp. ACCN 2016

[19] M. Kaleem GALAMALI, Assoc. Prof Nawaz MOHAMUDALLY, Model of Minimum Energy Consumption Ratio Achievable in MANET Using LocationAware Transmission in Ubicomp. ACCN 2016

[20] M. Kaleem GALAMALI, Assoc. Prof Nawaz MOHAMUDALLY, Model of Maximum Energy Consumption Ratio Achievable in MANET Using LocationAware Transmission in Ubicomp. ACCN 2016

[21] M. Kaleem GALAMALI, Assoc. Prof Nawaz MOHAMUDALLY, Model of Overall Energy Consumption Fairness Ratio Achievable in MANET Using LocationAware Transmission in Ubicomp. ACCN 2016

[22] M. Kaleem GALAMALI, Assoc. Prof Nawaz MOHAMUDALLY, Model of Overall Energy Consumption Fairness Proportion Achievable in MANET Using LocationAware Transmission for Ubicomp, CEET 2016

[23] M. Kaleem GALAMALI, Assoc. Prof Nawaz MOHAMUDALLY, Model of Minimum Fairness Proportion Achievable in MANET Using Location-Aware Transmission for Ubicomp, CEET 2016

[24] M. Kaleem GALAMALI, Assoc. Prof Nawaz MOHAMUDALLY, Model of Maximum Fairness Proportion Achievable in MANET Using Location-Aware Transmission for Ubicomp, CEET 2016

[25] M. Kaleem GALAMALI, Assoc. Prof Nawaz MOHAMUDALLY, Model of Sender Fairness Proportion Achievable in MANET Using Location-Aware Transmission for Ubicomp, CEET 2016

[26] M. Kaleem GALAMALI, Assoc. Prof Nawaz MOHAMUDALLY, Model of Distance Travelled by packets in MANETs using Location-Aware Transmission for Ubicomp, CEET 2016

[27] M. Kaleem GALAMALI, Assoc. Prof Nawaz MOHAMUDALLY, Model of Maximum CBR Distance Travelled by packets in MANETs using Location-Aware Transmission for Ubicomp, CEET 2016

[28] M. Kaleem GALAMALI, Assoc. Prof Nawaz MOHAMUDALLY, Model of Minimum CBR Distance Travelled by packets in MANETs using Location-Aware Transmission for Ubicomp, CEET 2016

[29] M. Kaleem GALAMALI, Assoc. Prof Nawaz MOHAMUDALLY, Model of Range CBR Distance Experienced by Transmissions in MANETs using LocationAware Transmission for Ubicomp, CEET 2016

[30] M. Kaleem GALAMALI, Assoc. Prof Nawaz MOHAMUDALLY, Trend Analyses of Parameters of Equations for Sender Node Energy Savings Achievable in ubicomp MANETs using Location-Aware Transmission, ACCN 2017.

[31] M. Kaleem GALAMALI, Assoc. Prof Nawaz MOHAMUDALLY, Trend Analyses of Parameters of Equations for Overall Node Energy Savings Achievable in ubicomp MANETs using Location-Aware Transmission, ACCN 2017

[32] M. Kaleem GALAMALI, Assoc. Prof Nawaz MOHAMUDALLY, Trend Analyses of Parameters of Equations for Sender Node Extra Energy Savings Achievable in MANET against Direct Node-to-Node Location-Aware Transmission, ACCN 2017.

[33] M. Kaleem GALAMALI, Assoc. Prof Nawaz MOHAMUDALLY, Trend Analyses of Parameters of Equations for Overall Nodes Extra Energy Savings Achievable in MANET against Direct Node-to-Node Location-Aware Transmission, ACCN 2017.

[34] M. Kaleem GALAMALI, Assoc. Prof Nawaz MOHAMUDALLY, Trend Analyses of Parameters of Equations for Energy Consumption Ratio Achievable in Ubicomp MANET Using Location-Aware Transmission, ACCN 2017.

[35] M. Kaleem GALAMALI, Assoc. Prof Nawaz MOHAMUDALLY, Trend Analyses of Parameters of Equations for Minimum Energy Consumption Ratio Achievable in Ubicomp MANETs Using Location-Aware Transmission, ACCN 2017.

[36] M. Kaleem GALAMALI, Assoc. Prof Nawaz MOHAMUDALLY, Trend Analyses of Parameters of Equations for Maximum Energy Consumption Ratio Achievable in Ubicomp MANETs Using Location-Aware Transmission, ACCN 2017.

[37] M. Kaleem GALAMALI, Assoc. Prof Nawaz MOHAMUDALLY, Trend Analyses of Parameters of Equations for Overall Fairness Ratio Achievable in Ubicomp MANETs Using Location-Aware Transmission, ACCN 2017.

[38] M. Kaleem GALAMALI, Assoc. Prof Nawaz MOHAMUDALLY, Trend Analyses of Parameters of Equations for Energy Consumption Fairness Proportion Achievable in Ubicomp MANETs Using Location-Aware Transmission, CEET 2017

[39] M. Kaleem GALAMALI, Assoc. Prof Nawaz MOHAMUDALLY, Trend Analyses of Parameters of Equations for Minimum Fairness Proportion Achievable in Ubicomp MANETs Using Location-Aware Transmission, CEET 2017

[40] M. Kaleem GALAMALI, Assoc. Prof Nawaz MOHAMUDALLY, Trend Analyses of Parameters of Equations for Maximum Fairness Proportion Achievable in Ubicomp MANETs Using Location-Aware Transmission, CEET 2017

[41] M. Kaleem GALAMALI, Assoc. Prof Nawaz MOHAMUDALLY, Trend Analyses of Parameters of Equations for Sender Fairness Proportion Achievable in Ubicomp MANETs Using Location-Aware Transmission, CEET 2017

[42] M. Kaleem GALAMALI, Assoc. Prof Nawaz MOHAMUDALLY, Trend Analyses of Parameters of Equations for Packets Per Distance Achievable in Ubicomp MANETs Using Location-Aware Transmission, CEET 2017

[43] M. Kaleem GALAMALI, Assoc. Prof Nawaz MOHAMUDALLY, Trend Analyses of Parameters of Equations for Maximum CBR Distance Achievable in Ubicomp MANETs Using Location-Aware Transmission, CEET 2017

[44] Markus Bylund and Zary Segall, Towards seamless mobility with personal servers, 2004.

[45] Masugi Inoue, Mikio Hasegawa, Nobuo Ryoki and Hiroyuki Morikawa, Context-Based Seamless Network and Application Control, 2004

[46] Xiang Song, Umakishore Ramachandran, MobiGo: A Middleware for Seamless Mobility, College of Computing Georgia Institute of Technology, Atlanta, GA, USA, August 2007

[47] Budzisz, Ferrús, R., Brunstrom A., Grinnemo, K, Fracchia R., Galante, G., and Casadevall, F. Towards transport-layer mobility: Evolution of SCTP multihoming, March 2008

[48] Paul Dourish \& Genevieve Bell, Divining a digital future, 2011

[49] Xiang Song, Seamless Mobility In Ubiquitous Computing Environments, PhD Thesis, Georgia Institute of Technology, August 2008

[50] Kevin O Mahony, Jian Liang, Kieran Delaney, User-Centric Personalization and Autonomous Reconfiguration Across Ubiquitous Computing Environments, NIMBUS Centre Cork Institute of Technology, Cork, Ireland, UBICOMM 2012

[51] Pablo Vidales, Seamless mobility in 4G systems, Technical Report, University of Cambridge, Computer Laboratory, 
Number 656, November 2005

[52] João Pedro Sousa and David Garlan, Aura: An Architectural Framework for User Mobility in Ubiquitous Computing Environments, School of Computer Science, Carnegie Mellon University, USA, August 2002

[53] Dennis Lupiana, Ciaran O'Driscoll, Fredrick Mtenzi, Defining Smart Space in the Context of Ubiquitous Computing, Dublin Institute of Technology, Ireland, Special Issue on ICIT 2009 Conference - Web and Agent Systems, 2009

[54] N.S.V.Shet1, Prof.K.Chandrasekaran2 and Prof. K.C.Shet3, WAP Based Seamless Roaming In Urban Environment with Wise Handoff Technique, International Journal of UbiComp (IJU), Vol.1, No.4, October 2010

[55] Yipeng Yu Dan He Weidong Hua Shijian Li Yu Qi Yueming Wang Gang Pan, FlyingBuddy2: A Braincontrolled Assistant for the Handicapped, Zhejiang University, UbiComp'12, September 5-8, 2012.

[56] Jing Su, James Scott, Pan Hui, Jon Crowcroft, Eyal de Lara Christophe Diot, Ashvin Goel, Meng How Lim, and Eben Upton, Haggle: Seamless Networking for Mobile Applications, 2007

[57] Rui Han, Moustafa M. Ghanem, Li Guo, Yike Guo*, Michelle Osmond, Enabling cost-aware and adaptive elasticity of multi-tier cloud applications, Future Generation Computer Systems, 2012

[58] Byrav Ramamurthy, K. K. Ramakrishnan, Rakesh K. Sinha, Cost and Reliability Considerations in Designing the NextGeneration IP over WDM Backbone Networks, 2012.

[59] Bhavish Aggarwal, Aditya Akella, Ashok Anand, Athula Balachandran, Pushkar Chitnis, Chitra Muthukrishnan, Ram Ramjee and George Varghese, EndRE: An End-System Redundancy Elimination Service for Enterprises, NSDI 2010, San Jose, CA

[60] Ashok Anand, Vyas Sekar and Aditya Akella, SmartRE: An Architecture for Coordinated Network-wide Redundancy Elimination, SIGCOMM 2009, Barcelona, Spain

[61] John Breeden II, "Smart-phone battery life could double without better batteries", Nov 14, 2012

[62] Andy Boxall, "When will your phone battery last as long as your kindle", December 5, 2012.

[63] Imielinski, T. and Navas, J.C. (1999). GPS-based geographic addressing, routing, and resource discovery. Comms. ACM, Vol. 42, No. 4, pp. 86-92.

[64] Hightower, J. and Borriello, G. (2001). Location Systems for Ubiquitous Computing. IEEE Computer, Vol. 34, No. 8, August, pp. 57-66.

[65] Harter, A., Hopper, A., Steggles, P., Ward, A. and Webster, P. (2002). The Anatomy of a Context-Aware Application. Wireless Networks, Vol. 8, No. 2-3, Mar-May, pp. 187-197.

[66] Hightower, J., Brumitt, B. and Borriello, G. (2002). The Location Stack: A Layered Model for Location in Ubiquitous Computing. Proceedings of the 4th IEEE Workshop on Mobile Computing Systems \& Applications (WMCSA 2002), Callicoon, NY, USA, June, pp. 22-28.

[67] Graumann, D., Lara, W., Hightower, J. and Borriello, G. (2003). Real-world implementation of the Location Stack: The Universal Location Framework. Proceedings of the 5th IEEE Workshop on Mobile Computing Systems \& Applications (WMCSA 2003), Monterey, CA, USA, October, pp. 122-128.

[68] Ko, Y., \& Vaidya, N. H. (2000). Location-aided routing (LAR) in mobile ad hoc networks. Wireless Networks, 6(4), 307-321.

[69] Liao, W.-H., Tseng, Y.-C., \& Sheu, J.-P. (2001). GRID: a fully location-aware routing protocol for mobile ad hoc networks. Telecommunication Systems, 18(1), 37-60.

[70] Kuhn, F., Wattenhofer, R., Zhang, Y., \& Zollinger, A. (2003). Geometric ad-hoc routing: of theory and practice. In Proceedings of the ACM (PODC'03) (pp. 63-72).

[71] Jiang, X., \& Camp, T. (2002). Review of geocasting protocols for a mobile ad hoc network. In Proceedings of the Grace Hopper Celebration (GHC).
[72] Ko, Y. \& Vaidya, N. H. (1999). Geocasting in mobile ad hoc networks: location-based multicast algorithms. In Proceedings of the IEEE (WMCSA'99) (pp. 101).

[73] Mauve, M., Fuler, H., Widmer, J., \& Lang, T. (2003) Position-based multicast routing for mobile ad-hoc networks (Technical Report TR-03-004). Department of Computer Science, University of Mannheim.

[74] Xu, Y., Heidemann, J., \& Estrin, D. (2001). Geographyinformed energy conservation for adhoc routing. In Proceedings of the ACM/IEEE (MOBICOM'01) (pp. 70-84).

[75] Hu, Y.-C., Perrig, A., \& Johnson, D. (2003). Packet leashes: a defense against wormhole attacks in wireless ad hoc networks. In Proceedings of the INFOCOM’ 03 (pp. 19761986).

[76] Patwari, N., Hero III, A. O., Perkins, M., Correal, N. S., \& O'Dea, R. J. (2003). Relative location estimation in wireless sensor networks. IEEE Transactions on Signal Processing, 51(8), 2137-2148.

[77] Baldauf, M., Dustdar, S., \& Rosenberg, F. (2007). A Survey on Context Aware Systems. International Journal of Ad Hoc and Ubiquitous Computing, Inderscience Publishers. forthcoming. Pre-print from: http://www.vitalab.tuwien.ac.at/ florian/papers/ijahuc2007.pdf

[78] Hong, D., Chiu, D.K.W., \& Shen, V.Y. (2005) Requirements elicitation for the design of context-aware applications in a ubiquitous environment. In Proceedings of ICEC'05 (pp. 590-596)

[79] Neeraj Tantubay, Dinesh Ratan Gautam and Mukesh Kumar Dhariwal, A Review of Power Conservation in Wireless Mobile Ad hoc Network (MANET)", International Journal of computer Science Issues, Vol 8, Issue 4, No 1, July 2011.

[80] Wenrui Zhao, Mostafa Ammar and Ellen Zegura, "A

Message Ferrying Approach for Data Delivery in Sparse Mobile Ad Hoc Networks", MobiHoc'04, May 24-26, 2004, Roppongi, Japan.

About Author (s):

Associate Professor Nawaz Mohamudally works at University of Technology, Mauritius (UTM) and has undertaken supervision of MPhil/PhD Students for many years.

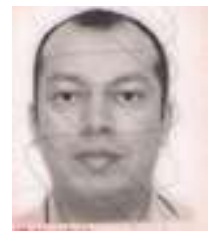

M. Kaleem Galamali is a part-time student (achieved M Phil Transfer on 28.10.2014, currently $\mathrm{PhD}$ student) at UTM under supervision of A.P. Nawaz Mohamudally. 